\title{
ANDREW RUTHERFORD DAVIDSON
}

ANDREW Davidson was born in 1890 and died in March 1968 in his 78th year. His later years-indeed since 1951 when ill health compelled his early retirement-werc marred by a progressive condition which sapped his physical activity but never dimmed his cheerful spirit, and so made visits to him something of an inspiration.

The youngest of eight children, he had an unusual upbringing in that his parents died in his infancy and he came under the devoted care of his uncle and aunt, $\mathrm{Mr}$ and Mrs Rutherford. His education was gained at Aylwin College, Westmorland (a private school which closed its doors soon after his departure-a sequence of events of which I used sometimes to remind him).

In 1910 he entered the service of the Edinburgh Office of the English \& Scottish-a company long since absorbed in the Eagle Star. Not finding this much to his taste, he afterwards joined-in 1914-the Standard. In the meantime his ambition had been fired to become an actuary, and to that end he became a pupil of Arthur Cockburn-an actuary who afterwards made a successful career in the U.S.A. It so happened that I was Cockburn's other pupil, a most happy accident for me, for we became close, lifelong friends; we studied together, passed all our examinations together, and in 1915 gained our Fellowship of the Faculty. The Army at once engulfed us, and when demobilization at last set us free, we parted again, he to the Standard and I to London.

Thereafter his progress up the official ladder followed a normal pattern until in 1942 he became Manager and Actuary, although he did for a time occupy the unusual position, for an actuary, of Agency Manager. The Standard was his ruling passion and he built it up to become the largest Scottish insurance company. He was indecd a man of many passions, some evanescent, others more enduring. He was, for instance, always a passionate Scot. He never left the borders of Scotland unless he had to. His other enduring passion was the Faculty, of which he was elected President in 1948, having served it in many capacities over the years.

His Presidential Address will be long remembered as a notable, scholarly essay on the implications (social, economic, political) arising from population changes. Two years later he contributed an outstanding essay on Probability. All of us constantly make use of the theory of probability in the calculations which are our daily task. Few among us pause to consider the theoretical validity of probability; and fewer still have written, as Davidson has done so enchantingly, in this philosophical dissertation, which is clearly the fruit of prolonged study and reflection. His greatest work, that which will ensure his name will live, is undoubtedly his 'History of the Faculty 1856-1956'. Herein he distils slices of Scottish history, biographical sketches of former leading actuaries, and on every page shining examples of his keen sense of humour, to form an intricate pattern that makes the book a delight to read. This is more than a history. It is a work of art.

He took little interest in sport, apart from watching Rugby football. In his later years, however, he took up fishing and chess. Becoming no mean performer in both these pastimes, he thus derived much pleasure in tranquillity.

In 1920 Davidson became an F.I.A., although in the nature of things he was able to make little contribution to the proceedings of the Institute. Nevertheless, there are many senior members who knew and respected him, and it seems altogether right and natural that some short memoir should appear in the Journal about this most exceptional man.

G. H. RECKNELL 